\title{
STRUCTURAL FOUNDATIONS OF SOCIAL RESILIENCE
}

\section{Hulya Dagdeviren*, Luis Capucha**, Alexandre Calado***, Matthew Donoghue ${ }^{\dagger}$ \& Pedro Estêvão ${ }^{\ddagger}$}

*Business School, University of Hertfordshire, h.dagdeviren@herts.ac.uk

** Dep of Political Sci \& Public Policy, Instituto Universitário de Lisboa, luis.capucha@iscte-iul.pt

*** Dep of Political Sci \& Public Policy Instituto Universitário de Lisboa, alexandre.calado@iscte-iul.pt

${ }^{\dagger}$ Dep of Social Policy \& Intervention, University of Oxford, matthew.donoghue@spi.ox.ac.uk

‡ Dep of Political Sci \& Public Policy, Instituto Universitário de Lisboa, estevao.pedro.Isb@gmail.com

This article aims to contribute to the theoretical development of the social resilience approach. Recognising the interface between resilience and poverty studies, it proposes a distinct role for resilience research from a critical perspective to understand the dynamics of hardship in exceptional times, such as times of socio-economic crises, rather than explaining the long-term trajectories of poverty. It then provides a conceptual framework on the structural foundations of social resilience, highlighting three components: rules, resources and power relations. The article uses the 2008 crisis and the ensuing period of austerity as a microcosm to place the discussion within a contemporary context.

Key words: Resilience, crisis, poverty, hardship, structure.

\section{Introduction}

There has been growing interest in the concept of resilience in social policy literature, especially against the backdrop of recent crisis and recession and their impacts on people's lives. The concept is often defined as the ability to bounce back, overcome the odds and make savvy use of resources, networks and support structures. This has given rise to a heroic notion of resilience which has been criticised extensively by scholars who highlight the conceptual inconsistencies in resilience analysis and its potential to justify certain ideological narratives. There is, therefore, a need to incorporate the social foundations of resilience into its conceptual framework to unpack the dynamics of resilience.

This article aims to contribute to the development of the resilience approach by conceptualising it from a critical perspective. We start by stressing the problematic nature of the concept when it is framed as an intrinsic individual attribute. Instead, we highlight that the fundamental role of social processes must be adequately accounted for in studies of resilience. In this stride, we reject the idea of resilience being an alternative to poverty studies, which is misleading and not always justified. Instead, we propose that poverty studies have distinct advantages in explaining long-term structural deprivations while the resilience view may be helpful in exploring the changing dynamics of hardship and how to counter it in times of crises. We then 
proceed to present a framework for the analysis of social resilience by unpacking socio-economic and political factors that may facilitate or hinder resilience in times of crisis and other major adversities.

In the next section, drawing on the literature, we provide some conceptual and methodological clarifications. Section 3 presents a discussion of structural foundations of resilience at three different levels. These are described as rule-based, power-based and resource- based foundations. For a more concrete understanding of their relationships with resilience, we discuss each of these elements in connection to the developments in the aftermath of the 2008 crisis. This is followed by policy implications of the discussion in the article and then a summary of conclusions in the final section.

\section{Conceptual clarifications in relation to the existing literature}

The emerging literature on resilience has established itself in contrast to poverty studies (Mohaupt, 2009). The basic criticism is that poverty studies emphasise a 'deficit model' which defines the poor in negative terms and views them as passive victims, rather than actors with some control over their circumstances (Canvin et al., 2009; Harrison 2012, Aldrich, 2012). Resilience studies, on the other hand, largely emphasise processes of turning crises into opportunities, making positive changes following setbacks and showing the ability to survive multiple pressures (Mullin and Arce, 2008, Seccombe 2012), although some studies have framed resilience in less heroic terms (Estêvão, et al., 2017), such as 'getting by' in the face of hardship (Batty and Cole, 2010).

Our argument is that the distinction between the two is not so much about viewing the poor in a positive or negative light but more to do with the method of analysis. Firstly, the positivity associated with resilience in some studies is a dubious imagination (Hickman, 2018). Not all risk management efforts and responses to shocks result in positive outcomes for wellbeing (Walker et al., 2002, Arnall, 2015). Recovery from economic shocks, seen as resilience, may be related to efforts and/or outcomes that are undesirable both individually and socially (Buchardt and Huerta, 2008). Cutting down on essential consumption such as food or heating, selling assets to cope with hardship, long hours of work and illegal work are some of the negative, and in some cases harmful, practices hidden behind the term resilience (Dagdeviren and Donoghue, 2019).

Secondly, studies of poverty focus on what they see as a social problem (Townsend, 1998, Nolan and Whelan 1996, Rowntree and Lavers, 1951). Overemphasis on individual responsibility in the resilience approach, on the other hand, depoliticises poverty and social inequality. Hence, without an appropriate framing, it may shift the attention away from social realities of life by focusing on individuals and their positivity (recovery, striving, success against setbacks, etc.) while downplaying the importance of improving material conditions of life and widening opportunities at a societal level. More importantly, framing resilience as an individual trait can result in those living in poverty being divided as resilient and non-resilient. So those in the latter category would still be victimised and treated with negativity within a resilience framework.

There is growing recognition, however, that resilience cannot be considered in isolation from historical, structural and social conditions. Some scholars argue that resilience is neither a personal trait nor an attribute, reflecting invulnerability. Instead, it is seen as contextual and domain specific. People may be resilient in one domain but not so in another or they may be resilient in a certain context but not in another (Bercht, 2013). Some scholars view resilience as a social and collective phenomenon (Revilla et al., 2018). There are calls for social power and rights to be integrated into the framework of resilience (Walsh-Dilley et al., 2016). Social resilience for Keck and Sakdapolrak (2013) is directly linked to politics, participation and power. Adger (2000) argues that 'social resilience should be defined at the level of community rather than being a phenomenon pertaining 
to individuals'. For Milne and Rankine (2013) resilience is explicitly social as well as economic, requiring the development and maintenance of robust social networks for the acquisition and deployment of resources and skills.

This article aims to contribute to this critical literature by developing a framework for the structural foundations of social resilience. A few conceptual clarifications are due before we set out to explain what this analytical framework looks like.

First, we argue that the resilience concept would be useful in investigating and understanding the impacts of, responses to and recovery from unexpected or expected but unpredictable (in terms of timing and/or nature, severity of shock) systemic or large scale natural, social, economic and political adversities in line with Martin and Sunley $(2012,2015)$. This means the resilience approach is not intended for long-term, persistent trajectories of disadvantageous states of living. Instead, it is used in the analysis of transitional dynamics of economic hardship in times of crisis (Estêvão et al., 2017). This is because such profound disruptions can fundamentally change the economic trajectories of not only poor but also non-poor households. Downward social mobility in times of crisis implies that previously well-off families may slip into poverty through job, activity or business losses. There is evidence that this has been happening in some countries in Europe (Vandecasteele, 2011; Dagdeviren et al., 2017).

Second, while we propose that the resilience approach should focus on crisis periods, we are also aware that resilience as a capacity is developed over longer-term periods (e.g. through investment in education and skills, health systems and social welfare). Hence, we highlight the structural foundations of resilience. Third, while some shocks (e.g. some natural disasters) may be unrelated to the workings of the social system (i.e. exogenous), it is important to recognise that most shocks in social contexts arise endogenously, directly or indirectly from the way societies function. For example, there is considerable consensus that the 2008 crisis arose due to excessive risk taking by financial institutions. These distinctions are relevant for policy making purposes. For example, while exogenous shocks may not be avoided, shocks arising from the fault-lines of social systems can be eliminated or ameliorated with appropriate interventions.

Finally, we refrain from using what economists call methodological individualism which often amounts to the generalisation of stereotyped individual experiences or explaining social phenomena with reference to individuals (Lukes, 1968; Arrow, 1994; Hodgson, 2007). In our view, resilience as a unique and inherent individual attribute is neither identifiable nor useful for policy purposes. Distinguishing people as resilient and non-resilient in this way is scientifically difficult, if not impossible, and normatively of little use (Dagdeviren et al., 2016). Dissection of individual resilience does not help us to fully understand resilience at a wider scale (groups, communities etc.) despite the interconnections between them. Furthermore, for practical and policy making purposes, wider shocks such as economic crises with societal impact cannot be effectively solved through individual action but require political action.

Overall then, four different conceptual clarifications are necessary for the purposes of this article: a) the focus is not on resilience as an individual attribute, b) resilience is not viewed as an alternative to poverty studies, c) resilience is most appropriate for unpacking the dynamics of economic hardship in times of crises rather than long-term deprivations, d) resilience capacity is developed in the long-term, hence it is important to understand the structural foundations of resilience. This article focuses on the last point, which is developed in detail in the next section with reference to the developments in relation to the 2008 crisis.

\section{Structural foundations of social resilience}


The resilience approach in social theory draws heavily on the theories of socio-ecological resilience ${ }^{1}$ and psycho-social resilience ${ }^{2}$ (Sapountzaki, 2012; Welsh, 2014; Revilla et al., 2018). While we recognise the valuable contributions these views have made, we also acknowledge their limitations. Theories of socio-ecological resilience usually suffer from absence of intentionality (involving cognition, reflexivity and consciousness in human action) that is embedded into social relations, including social hierarchies and power relations as well as their historical evolution (Giddens, 1984). Psycho-social resilience, on the other hand, takes social conditions as given.

The major proposition in this article is that social resilience analysis must take account of rules and resources together with power relations that bind and are bound by the two. The rules can be formal and informal but in the context of social resilience they include civil and social rights and entitlements and rules about social protection and operation of markets. Resource related aspects of social resilience require emphasis on distribution of wealth and income that is conducive for individuals to weather shocks and crisis, public investment in training and education that enhance access to and mobility in the labour market and provision of social protection that sustain individuals until recovery. The configuration of rules and distribution of resources determine power relations and are determined by them. Together these three elements of social systems can shape the nature of social resilience against major economic crises. This broad conceptualisation provides a basis for recognising the fact that resilience in times of crisis is likely to be uneven across different social groups.

Any analysis of social resilience should consider the given structure as well as the change and adaptation it may go through when subjected to a major shock. While the former reflects path dependence in the process of change the latter carries potential to diverge from it. In other words, resilience outcomes depend on existing as well as changing structure of rules, resources and power relations. Archer (2010) provides a more concise conceptualisation of these aspects which should be relevant for understanding the nature of social change in times of crisis and its implications for resilience. She highlighted diachronic and synchronic aspects to differentiate historical / cumulative from emergent structures. In the context of the discussion in this article, these could be considered as:

a) Diachronic underpinnings of change (or lack of change) after a crisis to highlight path dependence. These reflect the influence of initial conditions of rules, resources and power relations and their impact on resilience

b) Synchronic aspects of change (or lack of change) to emphasise the struggle for hegemony to maintain or re-shape the rules, distribution of resources and power in the aftermath of crises, with consequent impacts on resilience.

The ways diachronic and synchronic underpinnings of change work in reaction to major shocks generate variable impacts on different socio-economic groups and hence can create winners and losers. This is because they determine not only the nature of future rules and resource distributions but also how the cost of crisis is distributed.

Figure 1 reflects a simple picture of how societies can arrive at different structural outcomes following a potential reshuffling of power relations, rules and resource allocation in times of crises with different impacts on social resilience. For simplicity of illustration let us assume that there are two social groups which can be classified without difficulty in a homogenous way: workers and capitalists. Consider furthermore that power-based (or political) foundations of social resilience 
reflect the space for hegemonic power of capitalists and workers, rule-based (institutional) foundations of resilience reflect relative strength of rules that protect workers' and capitalists' interests and the resource based (economic) foundations of social resilience are reflected by the resources allocated to workers and capitalists. Figure 1 (i) represents the process of a potential restructuring/reformation, following a major crisis, of the initial conditions. Here HP is an abbreviation for hegemonic power and $K$ denotes capitalists while $L$ workers. Overlapping spaces of circles reflect power, rules and resources that serve common purpose. Let us start with an initial structure that is relatively balanced with similar strengths of workers and capitalist in terms of their power and resources as well as a relatively egalitarian structure of rules.

Figure 1. (i) Initial conditions, shock, action and struggle

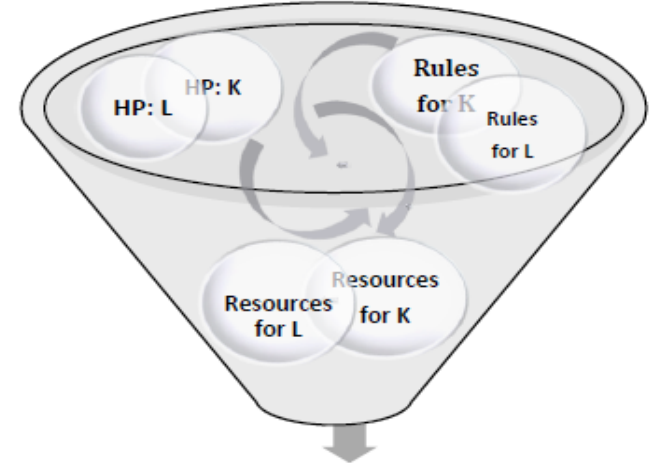

Alternative social structures emerging after the shock

(ii)

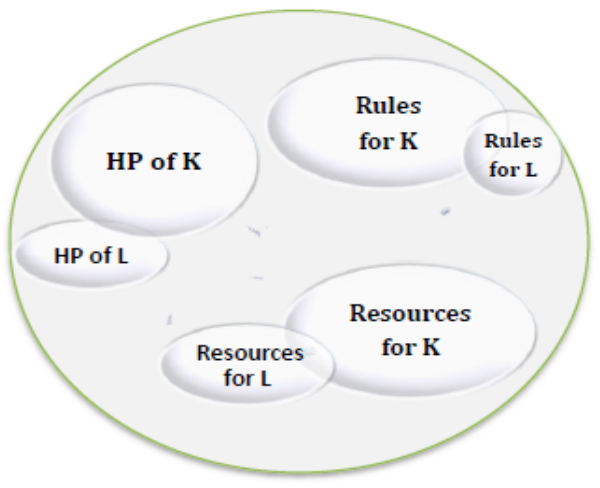

Note: HP is an abbreviation for hegemonic power, L and $\mathrm{K}$ denote labour and capital respectively. (iii)

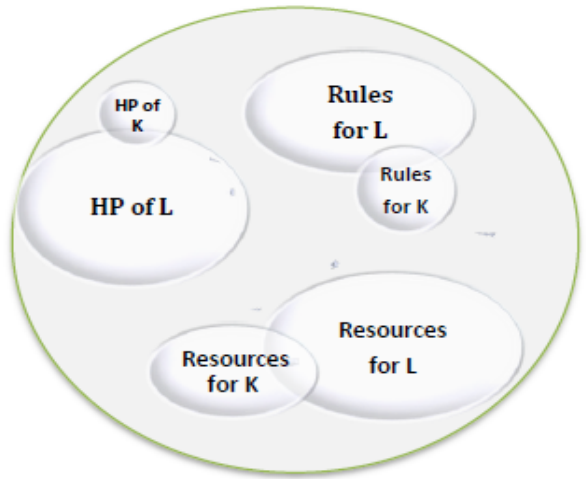

Crises can change the initial conditions in infinite ways given the complexity of class structures in modern societies. Again, for simplicity, we focus on two contrasting outcomes here, leaving the varieties of transitions in between to readers' imaginations. Case (ii) reflects a transition in which strength of power, rules of socio-economic conduct and allocation of resources changed in favour of capitalists. Case (iii), on the other hand, reflects a different transition in which social structure transitioned in favour of workers. Case (ii) would promote recovery of the conditions in favour of the capitalist class at the cost of working class with longer term disadvantages for the latter group. Case (iii) reflects the opposite.

Let us now discuss this simple picture in the context of the 2008 crisis for more concrete reflections on social resilience.

Recall the point made in the previous section - that economic crises are not exogenous (independent of social systems) but arise from the functioning of social structures. For example, the 
2008 crisis reflected the faults in the initial conditions of financial markets that generated instability through financial innovations (e.g. securitisation) and subprime lending which clearly played a significant role in the emergence of the crisis (Dymski, 2010; Rajan, 2010). The crisis threatened the existence of some financial institutions (Lehman Brothers, Northern Rock, etc.) and the viability of others. Repossession of houses led many families to lose the roof over their head, thus damaging their resilience and increasing their vulnerabilities. The initial conditions of rules and resources resulted in broad impacts, affecting both capitalists and workers, the former through losses in the financial markets and the latter through rising unemployment and unmanageable debt (Boorman, 2009; Basso et al., 2012).

However, hegemonic power relations led to modifications in rules and resource allocation. These manifested in austerity programmes which in many instances were against working classes and facilitated the socialisation of private risks and losses (Stiglitz, 2012; Mahnkopf, 2012). Such revisions illustrate the reformation in structural foundations of resilience, involving both the diachronic and synchronic aspects of change.

Let us expand on the rule-based foundations of resilience before discussing the revisions made to them in the post crisis period. These reflect formal and informal rules (including legal ones) with respect to the operation of markets and their regulation, social, economic and political freedoms, workings of the media, etc in generating stability or instability. For example, while labour markets and financial markets can potentially both create shocks and counteract against shocks, they can also reinforce or weaken resilience. The importance of initial conditions or diachronic underpinnings implies that economies with large informal or deregulated labour markets (lax rules in favour of capitalists) would see mass layoffs, following a crisis and economic downturn. Labour markets regulated to protect workers and conditions of employment, however, limit the scale of such actions. For those unable to escape unemployment, entitlements to social insurance and pension schemes have been probably the most important social resilience instruments in modern societies. This is also true for other types of social rights and social protection such as disability and sickness benefits and various sorts of income support.

Two contrasting examples may assist in illustrating how diachronically developed rules regarding social protection can synchronically be designed in ways that enable shocks to be absorbed with or without major social impacts. The first is the case of Germany which experienced one of the deepest economic contractions (around 6 per cent) in Europe in 2009. Despite this, the unemployment rate continued to decline from around 10 per cent in 2006 to 5 per cent in 2014 . Researchers point to the importance of 'short-time working allowances. This scheme existed in some form previously but was modified post crisis. Under this system, temporary reductions in work hours and pay, resulting from companies' declining sales, have been partly compensated by the government. This intervention has not only prevented a significant rise in unemployment but also enabled continued recovery in labour markets (Chung and Thewissesn, 2011). This collective buffer (in terms of its funding and universal coverage) rendered the need for 'individual resilience' redundant. The second is the case of the UK, which adopted a prolonged austerity programme that involved revisions to the rules of social protection. For example, an aggressive sanctions policy for the provision of social welfare benefits (Watts et al., 2014) has accompanied cuts to welfare benefits (OBR, 2016). These measures have weakened social resilience at a time when the unemployment rate more than doubled (Blanchflower, 2015). Attritions from the welfare system damaged the resilience of a significant proportion of the population as reflected by rising destitution, growing food poverty and the explosion in the use of foodbanks under austerity (Garthwaite, 2016; Dagdeviren et al., 2019; Dagdeviren and Donoghue, 2019). What is notable in the case of the UK is that the 
expectations for resilience are placed on the individual when the conditions that give rise to a need for resilience are structural.

The implementation of austerity programmes by many European countries in the aftermath of the 2008 crisis illuminates the political (power-based) foundations of resilience, highlighting the importance of power, participation and representation. Studies of economics on this subject heavily favour the view that austerity in the form of public spending cuts is counterproductive in times of crises and economic downturns (Keynes, 1937; Krugman, 2012; Blyth, 2013). One of the more notable consequences of austerity was a significant rise in poverty in countries such as Greece, Portugal and Spain where the at-risk-of-poverty rate rose significantly without much economic recovery and reduction in the sustainability of debt until very recently. The Portuguese case shows clearly that recovery was possible only after the end of austerity policies (Alderman, 2018).

The persistent application of austerity despite wide ranging evidence against it reflects a political choice (Blyth, 2013). At an abstract level, this is a manifestation of the hegemonic struggle for maintaining and/or deepening the status-quo of neo-liberal governance with its structures of power, institutions and resources in favour of the capitalist class. At a more practical level one may refer to the influence of corporate interests on political decision making as opposed to the lack of influence of unions (Drutman, 2015; Crouch, 2017). Overall, austerity programmes hampered the resilience of vulnerable groups through policies that favoured the interests of the powerful against the wider population (e.g. spending cuts, public sector restructuring, bank bailouts). While a considerable proportion of the population suffered through job losses, spending cuts and poverty, banks swiftly recovered their losses and registered profits soon after the crisis (Thompson, 2013; The Economist, 2017). The implication of this is that the balance and control over power structures through appropriate rules can prevent instability or help counter it.

Not only are political (power-based) and institutional (rule-based) foundations of resilience interdependent but also together they influence the distribution and redistribution of resources. The way assets, resources, wealth and income are distributed in a country has crucial implications for the resilience of individuals (Olsson, 2007). In principle, the influence on resilience can take effect in two ways.

First, the distributional stance of countries plays an important role in neutralising or aggravating the risks encountered by individuals and social groups. Concentration of wealth amongst a small proportion of the population implies that during a crisis those who are at greater risk (e.g. of losing jobs and shelter) will not have the resources to fall back on to 'beat the odds' or to 'bounce back'. For example, a study of household responses to hardship in post-crisis Europe found that, under austerity, coping through cutting down household expenditure has been most prevalent practice amongst low income families (Dagdeviren and Donoghue, 2019). In some cases, participants cut down on food to the point of 'hunger' or ignored medical necessities which clearly reflected a lack of choices (resulting from low incomes and inadequate savings) rather than resilience. Higher incomes for vulnerable groups (e.g. wages and salaries) would provide more opportunity to build up resources such as savings and housing - what Sen (1985) called 'endowments' - for them to fall back on in times of personal, localised or more systemic crises. Such endowments can enhance the potential for coping with the immediate consequences of shocks and help with the transition to a path of recovery.

Second, safety nets in the form of social transfers and social protection schemes provide short to medium term resilience by enabling individuals to absorb shocks to their incomes (for example through unemployment). In societies where poverty is widespread, the vulnerability to shocks is greater. Redistribution of wealth and incomes enhances resilience by improving the initial conditions of the poor and reducing the extent of vulnerabilities in challenging times. 
It is well documented that income distribution in the advanced capitalist societies has changed significantly since the 1980s in favour of the top one per cent earners and to the disadvantage of the 99 per cent (Atkinson et al., 2011; Barba and Pivetti, 2009). Inequality continued to rise after the crisis in countries that pursued austerity (Piketty, 2013). This is not accidental but the direct result of power relations (e.g. insistence on austerity) and configurations of rules (e.g. hegemonic political position against regulation of financial and labour markets to affect income distribution in favour of middle and low-income groups) (Blyth, 2013). In cases where social protection systems did not provide adequate support, transfers from family and faith-based organizations played an important role (Watson and Maître, 2013; Saraceno, 2017). On the one hand, use of welfare support was stigmatized by political elites (influencing the dispositions of the public and legitimacy of austerity), on the other hand, being dependent on family or community organizations such as foodbanks created a sense of failure and shame amongst the participants (Garthwaite, 2016; Dagdeviren et al., 2019). Limited prospects for new income sources during austerity and downturn led to unsustainable but unavoidable indebtedness. For example, Balasuriya et al., (2019) show that excessive debt for essential needs amongst low income groups has been one of the consequences of the austerity programme in Britain, which weakened their resilience. Organisations that provide debt advice to heavily indebted low-income groups indicate that another reason for vulnerability to debt on low incomes is the inability to accumulate resources and assets (e.g. savings) that families could draw on in times of hardship.

Overall, in this section we have argued that socio-economic crises often arise from the internal dynamics of social systems and can be remedied even if they are not avoidable. Resilience in such times requires structural underpinnings that are conducive to bouncing back and recovery. We described these as rule-based, power-based and resource-based underpinnings and operationalised these concepts in the context of the 2008 crisis. Two different forms of conflict and struggle in the process of transition after a major shock are particularly important to highlight: the diachronic (initial conditions of the structure before the crisis) and synchronic (hegemonic power struggle during the transition) aspects of resistance and change.

\section{Policy implications}

As we saw, austerity is a specific policy configuration of rules and resources pursued during and after the Great Recession. It is relevant for our discussion in as much as it undermines the conditions for social resilience. It follows that a social resilience approach must also be concerned with policy frameworks that, unlike austerity, strengthen the political, institutional and economic conditions for resilience. While drawing policy implications are difficult without reference to a specific context, broader reflections are possible. For a generic policy framework, we propose the following areas to constitute the primary focus. First, it is important to understand the temporal dimensions of resilience. This means paying attention to initial conditions of rules, resources and power and emerging vulnerabilities in the aftermath of crises and the timeframes of recovery assuming policies will not yield results immediately. Second, the notion of 'capacity' is crucial for resilience. Successful coping with crisis and/or transitioning to a better state requires social systems that protect individuals and enhance their ability to deal with shocks and adversities. Three distinct capacities for resilience are identified in the literature (Berkes et al., 2003; Bruneau et al., 2003; Keck and Sakdapolrak, 2013, Bene et al., 2015). One is coping or absorptive capacity which can be activated immediately after the shock (short-run). The other is adaptive capacity which requires an assessment of what is changing and what adjustments are necessary in the short to medium term. And the final one is transformative capacity that addresses the persistent, fundamental causes of risks through 
system level changes which in the context of this article involves social protection mechanisms, essential services, public assets etc.

We emphasise the importance of a rights-based view for resilience policy as advocated by Dean (2015) rather than ad hoc and irregular interventions to support resilience. In what follows, we aim to demonstrate the significance of such an approach with reference to four major rights, namely fundamental rights, employment rights, social rights and developmental rights. These rights have been in the forefront of institution building and policy making, especially in the post -World War II era. However, they have been eroded under the neoliberal governance ever since the 1980s.

Assuming that labour markets and social protection systems are the main channels through which resilience can be supported, the arguments for a rights-based approach to institute social resilience can be outlined in the following way:

a) Social rights, providing access to welfare benefits such as income or unemployment support, housing support or public health care, are the most prominent institutions of resilience, providing comprehensive support in times of systemic as well as local or personal crises. These public support systems boost the absorption capacity of individuals, families and social groups in the short-term and aid their adaptive capacity in the medium term.

b) Employment rights and the right to a decent wage would protect workers against spontaneous hire and fire practices, enable vulnerable populations to build their assets and resources in good times and allow them to fall back on those assets and resources in bad times. The implication is that an economic system, operating with race-to-the-bottom principles, involving precarious work and poverty wages, is damaging for social resilience both in good and bad times. For example, one of the most important sources of vulnerability amongst low income households is their lack of savings, implying limited absorptive capacity against the impact of minor or major crises. The inability to save is directly related to disadvantageous employment conditions and known to lead low-income families into unsustainable debt (Balasuriya, 2019).

c) Developmental rights such as right of access to knowledge, education and training are crucial for social resilience and are the most likely source of transformative capacity as they enhance the capabilities of individuals to overcome life's challenges (Sen, 1985; Backman and Nilsson, 2011). They provide general, job-specific and transferable skills, enabling mobility across markets, sectors, space and time as well as faster transition from unemployment to employment or better employment conditions. At a time when access to free education, healthcare and other public services is targeted with the pretext of reducing 'national debt', impacts of these policies on the transformative capacity of potentially excluded social groups are likely to continue into the foreseeable future.

d) Fundamental political rights such as freedoms of expression, association and assembly are essential to enhance political participation and counteract against socially regressive changes. Tackling the excesses of corporations, enforcing standards and penalising noncompliance to prevent instabilities and harmful consequences for wider society does not only require institutional capacity but also political balance, which depends on the effectiveness of fundamental rights such as legally grounded freedoms to challenge power and authority and organise for social and political causes. Relatedly, a strong and organised civil society is part of the social fabric that supports social resilience. This is reflected well, for example, by 
the prominent roles played by the law centres and citizen advice bureaus under austerity in Britain. They helped thousands of people, who have been affected through the austerity related welfare sanctions, by providing them with free legal advice, assisting with complex procedures and representing them in courts. In many instances, their help to challenge administrative decisions led to the reinstatement of the welfare benefits of affected individuals and prevented them slipping into destitution (Dagdeviren et al., 2019).

\section{Conclusions}

In this article, we have aimed to provide a theoretical framework for exploring structural foundations of social resilience. Critically engaging with the existing literature, we argued that resilience research ought to be about developing an understanding of the social conditions that enable individuals, groups and societies to limit and mitigate the negative impact of major shocks and facilitate recovery.

Our argument is that social resilience is shaped by three interrelated structural factors: power relations, formal and informal rules and distribution of resources. For a more practical exploration, the 2008 crisis has been used as a reference point to unpack the relationships between these factors and resilience.

Political (or power-based) foundations of resilience refer to how different forms of access to power, participation and representation boost or damage the resilience of different socioeconomic groups, classes and communities in the aftermath of shocks or crises. Institutional (rule-based) foundations of resilience, in turn, refer to the functioning of markets, law, regulatory rules and organizations, social protection schemes that are important for generating stability or instability and supporting or constraining resilience. These are shaped by path dependence on the one hand and struggles to change the rules and distribution of resources on the other hand. It is important to underline that power and rule-based foundations of resilience are intertwined and both heavily influence distribution of resources. The latter has crucial implications for mitigation or aggravation of the exposure of social groups to risks. The flow and stock of resources vulnerable groups have at their disposal are likely to heavily influence how they cope with crises and how speedily they can recover.

In sum, without conducive power relations, rules and resources for resilience, individuals may be overwhelmed by crises or may survive by coping through what Castel (1995) called 'disaffiliation' (loss of social ties). The outcome in this respect would partly depend on the severity of shocks, how they unfold (sudden or gradual) and the period in which they remain effective. Recovery from adversity, and even better, transforming to a better state of living, requires complementary rules, power structures and resource distributions that support vulnerable social groups to avoid being overwhelmed or stuck in survival mode and enable them to recover and ideally move to a better state. Shifting cost/burden of wider socio-economic risks on individuals cannot be an effective strategy for developing capacity for resilience.

The article highlights a rights-based approach for policy making purposes to enhance resilience, as collective risk management mechanisms such as Welfare State provisions are the most effective means of social resilience against expected, unexpected and unpredictable risks that societies may encounter.

\section{Acknowledgements}


The research leading to the results reported and discussed in this article has received funding from the European Union Seventh Framework Programme, FP7 - SSH-2013-2 Call 5.1.1 'Citizens Resilience in Times of Crisis' under grant agreement No 613245 RESCUE - 'Patterns of Resilience during Socioeconomic Crises among Households in Europe'.

\section{Notes}

1 This view emphasises systemic and structural aspects of resilience, involving continuous adaptive cycles of growth, accumulation, restructuring and renewal (Berkes and Folke, 1998; Holling, 2001; Rose, 2007).

2 Psycho-social resilience is about how individuals cope with risk through positive adaptation (Bercht, 2013; Werner, 1995).

\section{References}

Adger, W.N. (2000) 'Social and ecological resilience: are they related?', Progress in Human Geography, 24, 3, 347-64.

Alderman, L. (2018) 'Portugal dared to cast aside austerity. It's having a major revival', New York Times, 22 July.

Aldrich, D. (2012) Building Resilience: Social Capital in Post-disaster Recovery, Chicago: University of Chicago Press.

Archer, M. (2010) 'Morphogenesis versus structuration: on combining structure and action', The British Journal of Sociology, 61, S1, 225-52.

Arnall, A. (2015) 'Resilience as transformative capacity: exploring the quadripartite cycle of structuration in a Mozambican resettlement programme' Geoforum, 66, 26-36.

Arrow, K.J. (1994) 'Methodological Individualism and social knowledge', the American Economic Review, 84, 2, 1-9.

Atkinson, A., Picketty, T. and Saez, E. (2011) 'Top incomes in the long run of history', Journal of Economic Literature, 49, 1, 3-71.

Backman, O. and Nilsson, A. (2011) 'Pathways to social exclusion- a life-course study', European Sociological Review, 27, 107-23.

Balasuriya, J., Dagdeviren, H., Luz, S., Malik, A. and Shah, H. (2019) 'Financialisation, welfare retrenchment and subsistence debt in Britain', New Political Economy, 2019, https://doi.org/10.1080/13563467.2019.1570102.

Basso, G., Dolls, M., Eichhorst, W., Leoni, T and Peichl, A. (2012) The Effects of the Recent Economic Crisis on Social Protection and Labour Market Arrangements across Socio-Economic Groups, Institute of Labour Economics (IZA) Working Paper, IZA DP No. 6080

Barba, A. and Pivetti, M. (2009) 'Rising household debt: its causes and macroeconomic implicationsa long-period analysis', Cambridge Journal of Economics, 33, 1, 113-37.

Batty, E. and Cole, I. (2010) 'Resilience and the recession in six deprived communities?', York: JRF Programme Paper: Poverty and Place Programme, https://www.jrf.org.uk/report/resilienceand-recession-six-deprived-communities-preparing-worse-come [accessed 02.10.2019].

Béné, C., Frankenberger, T. and Nelson, S. (2015) 'Design, monitoring and evaluation of resilience interventions', Working Paper No. 459, Brighton: IDS, http://www.ids.ac.uk/publication/design-monitoring-and-evaluation-of-resilienceinterventions-conceptual-and-empirical-considerations [accessed 02.10.2019]. 
Bercht, A. (2013) 'Resilience in face of changing living conditions in Guangzou, China' Erkunde, 67, 1, 63-74.

Berkes, F. and Folke, C. (1998) Linking Social and Ecological Systems: Management Practices and Social Mechanisms for Building Resilience. Cambridge: Cambridge University Press.

Berkes, F., Colding, J. and Folke, C. (eds) (2003) Navigating Social-Ecological Systems: Building Resilience for Complexity and Change, Cambridge, UK: Cambridge University Press.

Blanchflower, D. G. (2015), 'As good as it gets? The UK labour market in recession and recovery', National Institute Economic Review, 231: F76-80

Blyth M (2013) Austerity: The History of a Dangerous Idea, Oxford: Oxford University Press.

Boorman, J. (2009) The Current Financial Crisis: Its Origins, Its Impact, and the Needed Policy Response, Global Journal of Emerging Market Economies, 1, 2, 127-135

Bruneau, M., Chang, S., Eguchi, R., Lee, G., O'Rourke, T., Reinhorn, A., Shinozuka, M., Tierney, K., Wallace, W. and von Winterfeldt, D. (2003) 'A framework to quantitatively assess and enhance the seismic resilience of communities', Earthquake Spectra, 19, 4, 733-52.

Buchardt, T. and Huerta, M. (2008) 'Introduction: resilience and social exclusion', Social Policy and Society, 8, 59-61.

Canvin, K., Marttila, A., Burstrom, B. and Whitehead, M. (2009) 'Tales of the unexpected? Hidden resilience in poor households in Britain', Social Science and Medicine, 69, 2, 238-45.

Castel, R. (1995) Les Métamorphoses De La Question Social, Paris: Fayard.

Chandler, D. (2013) 'International state-building and the ideology of resilience', Politics, 33, 4, $276-$ 86.

Chung, H. and Thewissen, S. (2011) 'Falling back on old habits? A comparison of the social and unemployment crisis reactive policy strategies in Germany, the UK and Sweden', Social Policy and Administration, 45, 4, 354-70.

Crouch, C. (2017) 'Membership density and trade union power', Transfer: European Review of Labour and Research, 23, 1, 47-61.

Dagdeviren, H. and Donoghue, M. (2019) 'Resilience, agency and coping with hardship: evidence from Europe during the Great Recession', Journal of Social Policy, 48, 8, 547-67.

Dagdeviren, H., Donoghue, M. and Wearmouth, A. (2019) 'When rhetoric does not translate to reality: hardship, empowerment and the third sector under austerity localism', The Sociological Review, 67, 1, 143-160.

Dagdeviren, H., Donoghue, M. and Meier, L. (2017) 'The narratives of hardship: the new and old poor in the aftermath of the 2008 crisis in Europe', The Sociological Review 65, 2, 369-85.

Dagdeviren, H., Donoghue, M. and Promberger, M (2016) 'Resilience, hardship and social conditions', Journal of Social Policy, 45, 1, 1-20.

Dean, H. (2015) Social Rights and Human Welfare, London: Routledge.

De la Rocha, M.G. (2006) 'Vanishing assets: cumulative disadvantage among the urban poor', Annals of the American Academy of Political and Social Science, 606, 1, 68-94.

Drutman, L. (2015) The Business of America is Lobbying, Oxford University Press, New York.

Dymski, G. (2010) Why the subprime crisis is different: a Minskyian approach, Cambridge Journal of Economics, 34, 2, 239-55.

Estêvão, P, Calado, A. and Capucha, L. (2017) 'Resilience: moving from a 'heroic' notion to a sociological concept', Sociologia Problemas e Práticas, 85, Lisboa: Editora Mundos Sociais, 915.

EU (2012) 'The EU approach to resilience: learning from food security crisis', Brussels: European Commission 


\section{http://ec.europa.eu/echo/files/policies/resilience/com 2012586 resilience en.pdf}

[accessed 02.10.2019].

Garthwaite, K. (2016) Hunger Pains: Life Inside Foodbank Britain, Bristol: Policy Press.

Giddens, A. (1984) The Constitution of Society, Cambridge: Polity.

Harrison, E. (2012) 'Bouncing back? Recession, resilience and everyday lives', Critical Social Policy, 33, 1, 97-113.

Hickman, P. (2018) 'A flawed construct? Understanding and unpicking the concept of resilience in the context of economic hardship' Social Policy and Society, 17, 3, 409-24.

Hodgson, G.M. (2007) 'Meanings of methodological individualism', Journal of Economic Methodology, 14, 2, 211-26.

Holling, C.S. (2001) 'Understanding the complexity of economic: ecological, and social systems', Ecosystems, 4, 5, 390-405.

Keck, M. and Sakdapolrak, P. (2013) 'What is social resilience?', Erkunde, 67, 1, 5-19.

Keynes, J.M. (1937) 'The general theory of employment', Quarterly Journal of Economics,

Krugman, P. (2012) End This Depression Now, W. W. Norton \& Company

Lukes, S. (1968) 'Methodological Individualism Reconsidered', The British Journal of Sociology, 19, 2, 119-129

MacLeavy, J. (2011) 'A 'new politics' of austerity, workfare and gender?', Cambridge Journal of Regions, Economy and Society, 4, 3, 355-67.

Mahnkopf, B. (2012) 'The euro crisis: German politics of blame and austerity - a neoliberal nightmare', International Critical Thought, 2, 4, 472-85.

Martin, R. and Sunley, P. (2012) 'The place of path dependence in an evolutionary perspective on the economic landscape', in R. Boschma and R. Martin (eds.), Handbook of Evolutionary Economic Geography, Chichester: Edward Elgar, 62-92.

Martin, R. and Sunley, P. (2015) 'On the notion of regional economic resilience: conceptualization and explanation', Journal of Economic Geography, 15, 1, 1-42.

Milne, A. and Rankine, D. (2013) 'Reality, resources, resilience: regeneration in a recession' York: JRF Programme Paper, https://www.jrf.org.uk/report/reality-resources-resilience-regenerationrecession.

Mohaupt, S. (2009) 'Review article: resilience and social exclusion', Social Policy and Society, 8, 1, 6371.

Mullin, W. J. and Arce, M. (2008) 'Resilience of families living in poverty', Journal of Family Social Work, 11, 4, 424-40.

Nolan, B. and Whelan, C.T. (1996) Resources, Deprivation, and Poverty, Oxford: Clarendon Press.

OBR (2016) 'October 2016 Welfare Trends Report' London: Office for Budget Responsibility

Olsson, E. (2007) 'The economic side of social relations: household poverty, adolescents' own resources and peer relations', European Sociological Review, 23, 4, 471-485.

Piketty, T. (2013) Le Capital au XXIeme Siécle, Paris: Seuil.

Rajan, R. (2010) Fault Lines: How Hidden Fractures Still Threaten the World Economy, Princeton, New Jersey: Princeton University Press.

Revilla, J. C., Martin, P. and de Castro, C. (2018) 'The reconstruction of resilience as a social and collective phenomenon: poverty and coping capacity during the economic crisis', European Societies, 20, 1, 89-110.

Rose, A. (2007) 'Economic resilience to natural and man-made disasters: multidisciplinary origins and contextual dimensions', Environmental Hazards, 7, 4, 383-98.

Rowntree, B. S. and Lavers, G. R. (1951) Poverty and the Welfare State, London: Longmans, Green \& Co. 
Saraceno, C. (2017) 'Southern Europe welfare regimes: from differentiation to reconvergence?', in P. Kennett and N. Lendvai-Bainton (eds), Handbook of European Social Policy, Cheltenham, UK: Edward Elgar, 218-29.

Seccombe, K. (2002) 'Beating the odds' versus 'changing the odds': poverty, resilience, and family policy', Journal of Marriage and Family, 64, 2, 384-94.

Sen, A. (1985) Commodities and Capabilities, Amsterdam: North-Holland.

Sapountzaki. K. (2012) 'Vulnerability management by means of resilience', Natural Hazards, 60, 3, 1267-85.

Stiglitz, J. (2012) The Price of Inequality, New York: W. W. Norton \& Company

The Economist (2017) 'Ten years on: a decade after the crisis, how are the world's banks doing?', Special Report, 6 May.

Thompson, D. (2013) 'Employment down, profits up: the aftermath of the financial crisis', The Atlantic, 13 September.

Townsend, P. (1998) 'Deprivation', Journal of Social Policy, 16, 2, 125-46.

Vandecasteele, L. (2011) 'Life course risks or cumulative disadvantage? The structuring effect of social stratification and life course events on poverty transitions in Europe', European Sociological Review, 27, 246-63.

Walker, B., Carpenter, S., Anderies, J., Abel, N., Cumming, G., Janssen, M., Lebel, L., Norberg, J., Peterson, G.D. and Pritchard, R. (2002) 'Resilience management in social-ecological systems', Conservation Ecology, 6, 1, 14-24.

Walsh-Dilley, M., Wolford, W. and McCarthy, J. (2016) 'Rights for resilience: bringing power, rights and agency into the resilience framework', Ecology and Society, 21, 1, 11 -21.

Watson, D. and Maître, B. (2013) 'Social transfers and poverty alleviation in Ireland: an analysis of the csoo survey on income and living conditions 2004-2011', Social Inclusion Report No.4. Dublin: Department of Social Protection and Economic and Social Research Institute.

Watts, B., Fitzpatrick, S., Bramley, G. and Watkins, D. (2014) 'Welfare sanctions and conditionality in the UK', York: Joseph Rowntree Foundation.

Welsh, M. (2014) 'Resilience and responsibility: governing uncertainty in a complex world', The Geographical Journal, 180, 1, 15-26.

Werner, E. E. (1995) 'Resilience in development', Current Directions in Psychological Science, 4, 3, 815. 